\title{
The Cross-Section of Expected Stock Returns in Brazil
}

\section{(Evidências seccionais dos retornos esperados das ações no Brasil)}

\author{
Gyorgy Varga* \\ Ricardo D. Brito
}

\begin{abstract}
In a sample of the Brazilian stock market from 1999 to 2015, this paper shows that the book-to-market and momentum of individual firms capture some of the cross-sectional variation in average stock returns, while the market $\beta$ and size do not play a role. The positive relation of cross-section of returns with book-tomarket is more evident earlier, while the positive relation with momentum is stronger later in the sample. However, because none of these characteristics show explanatory power for all the subsamples studied, we are not fully convinced that they capture fundamental risk factors.
\end{abstract}

Keywords: Book-to-market, Momentum and size characteristics, Emerging markets

JEL Codes: G11, G12, G14, N26.

Submetido em 22 de abril de 2016. Reformulado em 21 de junho de 2016. Aceito em 21 de junho de 2016. Publicado on-line em 27 de junho de 2016. O artigo foi avaliado segundo o processo de duplo anonimato além de ser avaliado pelo editor. Editor responsável: Márcio Poletti Laurini.

FCE, Rio de Janeiro, RJ, Brasil. E-mail: varga@fce.com.br.

***Insper, São Paulo, SP, Brasil. E-mail: RicardoDOB@insper.edu.

We appreciate the helpful comments of seminar participants at the XXXVII ENANPAD, 14th EBES (Barcelona), and 37o. EBE. We thank Ricardo Justo from Quantum finance for providing the data. All errors are our own. Ricardo Brito thanks the financial support of CNPq, under grant number 309343/2012-7.

Rev. Bras. Finanças (Online), Rio de Janeiro, Vol. 14, No. 2, June 2016, pp. 151-187 ISSN 1679-0731, ISSN online 1984-5146

(C)2016 Sociedade Brasileira de Finanças, under a Creative Commons Attribution 3.0 license http://creativecommons.org/licenses/by/3.0 


\section{Resumo}

Utilizando uma amostra do mercado acionário brasileiro entre 1999 e 2015, este artigo demonstra que características das firmas como a razão valor contábil/valor de mercado e o momento capturam parte da variação seccional dos retornos acionários, enquanto o $\beta$ de mercado e o tamanho não parecem importar. A relação positiva dos retornos seccionais com a razão valor contábil/valor de mercado é mais evidente no início, enquanto a relação positiva com o momento é mais forte no final da amostra. Entretanto, porque nenhuma destas caraterísticas apresenta poder explicativo em todas sub-amostras estudadas, não somos totalmente convencidos que elas capturam fatores de risco fundamental.

Palavras Chave: Book-to-market, Características de Momentum e Tamanho, Mercados Emergentes

\section{Introduction}

Fama and French (1992) - hereafter F\&F - and Jegadeesh and Titman (1993) convincingly summarized the evidence that "diversifiable" individual characteristics, like book-to-market, size and momentum, could capture important cross-sectional variation in average stock returns. Whether their combination of such characteristics capture some common risk factors, as in Fama and French $(1993,1996)$ three factor model, or some inefficiency as in Daniel and Titman (1997) is still being debated until today (see Campbell, 2014). If stocks with these characteristics are fundamentally riskier, we might expect them to continue to pay return premiums in the future. Investors who are less sensitive to these sources of risk will continue to enjoy their high returns. If, on the other hand, return premiums arose because of mispricing, we might expect these excess returns to fade away along time as investors learn about them.

Inspired by F\&F, Costa Jr. and Neves (2000) studied the Brazilian stock market for the period from March 1988 to February 1996 and found that not only the size and the book-to-market, but the portfolios' $\beta \mathrm{s}$ and earnings-to-price ratios were individually and jointly significant. The results of Braga and Leal (2003) are a little different, confirming that high book-to-market firms porfolios have greater average returns, but not that 
small size firms porfolios have greater average returns for the period July1991 - June1998. ${ }^{1}$

Regarding the momentum characteristic in Brazil, to the best of our knowledge, it has not been studied in a cross-section of individual stocks, but in the context of long-short strategies of good-bad momentum portfolios. For example, Bonomo and Dall'Agnol (2003) and Kimura (2003) do not find significant excess returns from these long-short strategies, while Piccoli et al. (2015) claim they do generate significant profits in normal periods that are used up during crises.

The short time span of data available in the early 2000s bounded deeper analyses. Qualitative and quantitative differences in this pioneering literature seem due to the inclusion or exclusion of a couple of years, given the influential weight of each included observations $(1 / \mathrm{N})$, what is specially an issue in a period of inflation stabilization that affected nominal returns (i.e., likely, changed the data generating process).

In this article, we review the explanatory power of the size, book-tomarket, leverage, and earnings-to-price characteristics of individual firms in Brazil, using a reliable sample of monthly stock returns and fundamentals variables from July 1999 to June 2015. Like F\&F, we find that the book-to-market of individual firms capture some of the crosssectional variation in average stock returns. In general, the patterns documented by $F \& F$ hold for the Brazilian stock market, with the qualification of less significance. Through the F\&F approach, we additionally document that the momentum of individual stocks measured as the cumulated returns over the past 2 to 12 months - has some explanatory ability. We find that the book-to-market is the most significant characteristic explaining the cross-section of stock returns in our most comprehensive sample, but that the momentum pattern is more evident in the subsample of more liquid stocks. When the July 1999 June 2014 period is split into two subperiods, none of the variables shows explanatory power in both sub-periods. The book-to-market relation with the cross-section of returns disappears in the later sub-period, when the

1 See Braga and Leal's (2003) literature review with the different authors' conclusions for the Brazilian market in the 1990s. 
momentum relation becomes noticeable. This last result is similar to Schwert (2002), who found that the abnormal return for characteristics such as size effect, value and others documented seem to have weakened, or simply disappeared, after the papers that highlighted them were published. Thus, through practitioners' exploration of these uncovered premiums, the research findings may have caused the market to become more efficient.

To more convincingly dismiss the market $\beta$ and size as sources of premiums, like F\&F in the Appendix, we look for the continuation of their premiums into the longer 27-year period, from July 1988 to June 2015, available at another database. Given the Brazilian inflation was much higher and variable before 1999, for comparability along different inflation regimes, we choose to work with real variables, i.e., constant prices instead of current nominal prices. We confirm that the market $\beta$ and size are not important for this whole longer period. Although they are significant in single characteristic regressions for the sub-period July 1999-June 2007, given the high correlation between the market $\beta$ and size, none of them is individually significant when they are used together.

Finally, we speculate on the issues of liquidity and governmentcontrolled firms. Liquidity and state governance risk are characteristics of special concern to investors in Brazil. For example, if growth stocks are more liquid (or less government-controlled) than value stocks, the value premium may in part reflect a compensation for the lower liquidity (or for greater state management inefficiency) of value firms.

We reveal traces that liquidity reduces the value premium, supporting the covariance hypothesis with liquidity risk. In the other direction, the momentum premium strengthens in the more liquid subsample, suggesting it is fostered by investors' active interest. Regarding government-control, we find no evidence of covariance with the firms' characteristics. Because government-controlled firms - which are larger in size and book-to-market - rewarded stockholder below the market average in the sample studied, their exclusion decreases the importance of the size effect and increases the importance of the value effect. 
The article proceeds as follows: The F\&F methodology used in this study is reviewed in section 2 . We describe our sample in section 3 and discuss our results in section 4. In section 5, we present some conclusions and suggest next steps in this research agenda.

\section{Methodology}

According to the efficient market hypothesis, all expected return in excess to the risk-free rate should be the "fair" reward to the investment's exposition to non-diversifiable systematic risk. In the CAPM, the most popular market efficient asset pricing model, all systematic risk is summarized in the market portfolio, thus implying that:

$$
E\left(\tilde{R}_{i, t}-R_{f, t}\right)=\beta_{i} E\left(\tilde{R}_{M, t}-R_{f, t}\right), \quad \forall i
$$

where: $E\left(\tilde{R}_{i, t}-R_{f, t}\right)$ is asset's i expected excess return over the riskfree rate $R_{f, t}$ during period $\mathrm{t}$ and $E\left(\tilde{R}_{M, t}-R_{f, t}\right)$ is the market portfolio expected excess return over the risk-free rate. In words, the CAPM states that asset i's premium comes from its covariance with the market portfolio $-\beta_{i}=\frac{\operatorname{cov}\left(\tilde{R}_{i, t}, \tilde{R}_{M, t}\right)}{\operatorname{var}\left(\tilde{R}_{M, t}\right)}$ and not from its own variance - and is linear in the systematic risk incurred.

Since Black, Jensen and Scholes (1972) and Fama and MacBeth (1973), many tests of the CAPM have been proposed. Intuitively, they all boil down in estimating regressions like:

$$
\left(\tilde{R}_{i, t}-R_{f, t}\right)=\alpha_{i}+\beta_{i}\left(\tilde{R}_{M, t}-R_{f, t}\right)+\tilde{e}_{i}
$$


and testing whether the intercept $\alpha_{i}$ equals zero, with varying degrees of econometric sophistication and power (see also Gibbons Ross and Shanken 1989).

Alternatively, given that only non-diversifiable risks should be priced in efficient markets, non-arbitrage in the CAPM implies that:

$$
E\left(\tilde{R}_{i, t}-R_{f, t}\right)=\lambda^{M} \beta_{i}, \quad \forall i
$$

where: $\lambda^{M}$ is the price of the stock market risk (or, the market reward per unit of the stock market risk factor incurred).

One can thus, similar to Fama and MacBeth (1973), run the crosssection regression:

$$
\overline{R_{i, t}}=\lambda_{t}^{0}+\lambda_{t}^{M} \beta_{i}+v_{i} \quad \forall i, \text { for each } t
$$

where $\overline{R_{i, t}}$ is the proxy for stock i expected return (that can vary through time), ${ }^{2} \quad$ and test if $\lambda_{t}^{0}=R_{f, t}$ and $\lambda_{t}^{M}>0$ on average; i.e., $\overline{\lambda^{0}}=$ $\left(T^{-1} \sum_{t=1}^{T} R_{f, t}\right)$ and $\overline{\lambda^{M}}=\left(T^{-1} \sum_{t=1}^{T} \lambda_{t}^{M}\right)>0$. A $\overline{\lambda^{0}}$ significantly different from the average risk-free interest rate $\left(T^{-1} \sum_{t=1}^{T} R_{f, t}\right)$ means that stocks returned different than justified by their $\beta_{i}$ s sensitivities to the non-diversifiable risk, i.e., there is an arbitrage opportunity if this same pattern of average return can be extrapolated into the future.

Other risk factors or individual characteristics hypothesized to explain expected returns can also be included in (4) and allowed to vary over time. For example, F\&F regressed the month-by-month crosssection of returns on size and book-to-market, in addition to the market $\beta$, allowing these regressors to vary annually according their previous

\footnotetext{
${ }^{2}$ For example, $\overline{R_{i, t}}$ can be period $t$ return or some moving average.
}

156 Revista Brasileira de Finanças (Online), Rio de Janeiro, Vol. 14, N.2, June 2016 
year estimate (i.e., they are known by the investors before the return realization):

$$
\begin{gathered}
R_{i, t+\tau}=\lambda_{t+\tau}^{0}+\lambda_{t+\tau}^{M} \beta_{i, t-1}+\lambda_{t+\tau}^{M E} \ln \left(M E_{i, t-1}\right)+\lambda_{t+\tau}^{B M} \ln \left(B M_{i, t-1}\right) \\
+v_{i, t+\tau}, \quad \forall i, \text { for each }(t+\tau)
\end{gathered}
$$

where $t$ is every July, $(t-1)$ is every June , $\tau=0,1, \ldots, 11$ means $(t+\tau)$ goes from July to June of the following year, $M E_{i, t-1}$ is the market value of equity and $B M_{i, t-1}=\left(B E_{i, t-1} / M E_{i, t-1}\right)$ is the book value of equity to its market value; and test if $\overline{\lambda^{M}}, \overline{\lambda^{M E}}, \overline{\lambda^{B M}}$ are significantly different from zero. ${ }^{3}$ They thus examine whether the size and book-to-market characteristics of firms are priced among stocks, in addition to the $\beta_{i}$ s sensitivities to the market risk. Insignificant $\overline{\lambda^{M E}}$ and $\overline{\lambda^{B M}}$ mean that these diversifiable characteristics are not priced in the market, as it should be in an efficient market where the CAPM model is true model of risk. ${ }^{4}$ That is the main approach we follow below.

\footnotetext{
${ }^{3}$ To minimize collinearity with $M E_{i, t-1}, \mathrm{~F} \& \mathrm{~F}$ chose to use the value from previous December for $B M_{i, t-1}$.

${ }^{4}$ As Cochrane (2005) poses "It is true that expected returns are associated with or correlated with many such characteristics. Stocks of small companies or of companies with high book/market ratios do have higher average returns. But this correlation must be explained by some beta regression coefficient. The proper betas should drive out any characteristics in cross-sectional regressions. If, for example, expected returns were truly related to size, one could buy many small companies to form a large holding company. It would be a "large" company, and hence pay low average returns to the shareholders, while earning a large average return on its holdings of small companies. The managers could enjoy the difference. What ruins this promising idea? The "large", holding company will still behave like a portfolio of small stocks - it will have their high betas. Thus, only if asset returns depend on how you behave, not who you are - on betas rather than characteristics - can a market equilibrium survive such simple repackaging schemes."

@.) Revista Brasileira de Finanças (Online), Rio de Janeiro, Vol. 14, N. 2, June 2016 
As explained in Fama (1976), because the factors in equation (5) do not have the interpretation of risk premiums, $\lambda^{0}$ is not expected to be the average risk-free, but it is the return on a portfolio in which the weighted averages of the explanatory variables are 0 , i.e. $\ln \left(M E_{i}\right)=0$ and $\ln \left(B M_{i}\right)=0.5$

Additionally, we also follow F\&F approach of sorting stocks based on some ex-ante observable characteristics "to separate skill from luck", in Cochrane (2008) words. We present univariate descriptive statistics for the portfolios built to characterize the size and book-to-market effects, as well as the CAPM's $\beta$ systematic risk, that help to describe the crosssection of expected stock returns in Brazil.

\section{Data}

Our sample comes from Quantum ${ }^{6}$ and begins with companies made private, bankrupted, all stocks available at Bovespa during the sample period, therefore there is no survivorship bias. The São Paulo Stock Exchange has the totality of the stocks traded in Brazil since January 2000.

Traditionally in Brazil, there are Ordinary $(\mathrm{ON})$ and Preferred stocks (PN) for listed companies. The first one has more voting power and the last one has preference on the dividend payment. The PNs may also have different rights and are listed with an extra letter like: PN, PNA, PNB, PNC, PND, PNE, PNF and PNG. There are also the UNITs which are a set of ON e PN stocks. Also TPR which is special stock linked a commodity production and RCTB which is the right to subscribe a stock. For each company only one stock was kept, usually the PN stock because, in general, is the most traded one. We also excluded all stocks from foreign companies traded via BDR, stocks from banks due to their leverage and stocks from companies with negative book value for the

\footnotetext{
${ }^{5}$ For an econometric overview of the Fama and MacBeth approach, see also Shanken (1992).

${ }^{6}$ Quantum is a large provider of Brazilian financial market data. The data used here was downloaded in July, 2015 at www.quantumfinance.com.br.
} 
period that it has happened. Financial service companies like stock brokers, insurance and holding were maintained because they do not have such high leverage.

Several situations have affected the outstanding stocks:

- The ticker used in the stock exchange has changed due to the change in company name. We kept the whole stock history with the new name on.

- One type of stock is converted in another type, for example, all PNs are converted in ONs. We kept the longer series which will be the $\mathrm{ON}$ even if the PN were the most liquid.

- For each company only the most liquid (in this case the liquidity measure was trading for the longest time) one was selected, in some years one of them is more liquid than the other and we switch for the most liquid, therefore we do not have only one type of stock for each company in the whole period. If more than one stock is liquid enough we chose the PN type.

- The company has merged with another listed company and a new company is created, then we have two companies until the merge and a new one afterwards.

- One company purchases another company. We have two companies and the sold company has it series interrupted around the purchasing time.

The monthly return is calculated as:

$$
R_{i, t}=100 * \frac{P_{i, t}+D_{i, t}}{P_{i, t-1}}-1
$$

where: $P_{i, t-1}$ is the first closing price of the month $\mathrm{t}-1, P_{i, t}$ is the first closing price of month $\mathrm{t}$ and $D_{i, t}$ are the dividends and other payments to 
stockholders (like "interest on equity"). Liquidity in the Brazilian market is definitely a problem. As anticipated, if there is no price at the first business day $t$, then we get the first closing price in the next 10 business days. Thus, the return interval mismatched can have ten days at maximum. If there is no price within those days, then there is no month return. The stocks that miss returns for one month are excluded from the portfolio formed in that year, from July to June. The returns are calculated on local currency, the Brazilian Real (BRL).

The market value variable was based on total stocks (all types of stocks) outstanding times the stock price at the last day of June. If there is no stock price available, we used the available price up to 22 trading before the last business day of June, if there is no price available in this period, it is assumed no market value ${ }^{7}$.

Regarding the company's balance sheet data, all companies have published their individual statements and whenever they have parent companies, they were obliged to publish their consolidated statement (accordingly to the Brazilian regulation). We used the consolidated statements whenever it is available. It even occurs that some companies have published consolidated statements in some years and not in others, we continue to use the consolidated one for the years that it is available.

There are two potential problems in the accounting data. The change in the accounting standards from the Brazilian GAAP to the IFRS, that took place in 2010, and the lack of consolidated balance sheet for few companies in few years. The first problem does not affect the book value. To address the second problem, we use the individual balance sheet when available.

Another problem that affect flows, in our case, the cumulated earnings due to different closing of the fiscal year of some companies. The majority of the companies have their statements ending in December, but a few have it done in a different quarter. Therefore, in such cases we add up four quarters up to December, to get the annual earnings which maybe different than the annual one, due to accounting adjustments. The

\footnotetext{
${ }^{7}$ The Bovespa publish regularly market value to all listed stock, the stock price used is based on the last traded occured whenever it was.

160 Revista Brasileira de Finanças (Online), Rio de Janeiro, Vol. 14, N.2, June 2016
} 
earnings figures come from operating profits after taxes, associates, noncontrolling interest, discontinued operations and minority interest, which in Brazil is called consolidated net income of the controlling company.

Few stocks started trading in the middle of the year but did have their balance sheet published at the end of the former year (although did not have ME in December). In these cases, we got the next available ME as long as it is before the start of our portfolio (July). One problem that may distort the relationship $\mathrm{BE} / \mathrm{ME}$ in cases like these, is any corporate action like big asset sale or stock subscription, that decrease or increase the company book value, because of the time mismatch between BE (from December) and ME (from a future month). The ME shall reflect a different BE. In cases like these we use the BE published at the same quarter of the ME used.

After all considerations above, we end up with 419 stocks traded in Brazil from July 1997 to June 2015, which fulfill the requirement of at least one trade in the first ten days of the month in all the twelve months from July to June. Because we need at least two years of monthly returns to estimate betas before the first year of actual test, we additionally exclude 87 stocks in the sample that have less than 36 contiguous observations. We are thus left with an unbalanced panel of 332 stocks from July 1999 to June 2015, comprising 192 months, described in Table 1 .

Below, following $\mathrm{F} \& \mathrm{~F}$, in June of each year, we form equally weighted portfolios of stocks based on their characteristics, like market value of equity $(M E)$, book-to-market ratio $(B M=(B E / M E)), \quad \beta_{i} \mathrm{~s}$, leverage ratios and earnings-to-price ratio. Only stocks with returns for every month in the year following June are included in the portfolios. For example, sorting on the size dimension $(M E)$, we form five quintile portfolios. Within each size quintile, sorting on the book-to-market dimension $(B M)$, we form five book-to-market portfolios, totaling 25 "two-pass" ME- $B M$ portfolios. Another analyzed set of 25 portfolios is the pre- $\beta x M E$ sorting. To minimize multicollinearity problems, we observe the size values as of June and the book-to-market values as of December of the previous year. 
Table 1

Sample Summary

\begin{tabular}{cccccc}
\hline Year & $\begin{array}{c}\text { Sample market } \\
\text { value }\end{array}$ & $\begin{array}{c}\text { Sample number } \\
\text { of companies }\end{array}$ & $\begin{array}{c}\text { Ibovespa total } \\
\text { market value } \\
\text { (include banks) }\end{array}$ & $\begin{array}{c}\text { Bovespa total } \\
\text { market value }\end{array}$ & $\begin{array}{c}\text { Total number of } \\
\text { listed companies }\end{array}$ \\
\hline 1998 & 173 & 107 & 119 & 194 & 527 \\
1999 & 106 & 142 & 277 & 409 & 478 \\
2000 & 268 & 134 & 300 & 441 & 459 \\
2001 & 282 & 130 & 294 & 430 & 428 \\
2002 & 278 & 121 & 294 & 438 & 399 \\
2003 & 293 & 133 & 494 & 677 & 369 \\
2004 & 488 & 135 & 642 & 905 & 358 \\
2005 & 629 & 130 & 841 & 1128 & 343 \\
2006 & 787 & 152 & 1181 & 1545 & 350 \\
2007 & 1164 & 198 & 1765 & 2478 & 404 \\
2008 & 1729 & 209 & 1088 & 1375 & 392 \\
2009 & 993 & 207 & 1740 & 2335 & 385 \\
2010 & 1708 & 214 & 2071 & 2569 & 381 \\
2011 & 1867 & 221 & 1834 & 2294 & 373 \\
2012 & 1685 & 221 & 1962 & 2524 & 362 \\
2013 & 1904 & 215 & 1890 & 2414 & 363 \\
2014 & 1708 & 215 & 1824 & 2243 & 366 \\
\hline
\end{tabular}

Notes: Values are in BRL billions.

Source: Quantum and Bovespa

Other variables like the leverage and earnings-to-price are also observed in December of the year preceding June. Similar to in F\&F, the stocks' $\beta_{i}$ s are estimated on 60 monthly returns preceding July of every year (as available) to pre-rank them. The $\beta$ attributed to a stock in the tests is actually the $\beta$ of the portfolio formed from sorts of stocks on size and $\beta$ s to which the stock belongs. Although the $\beta$ s of the 25 portfolios do not vary along time, the $\beta$ of the stock can vary as it moves in the size and pre- $\beta$ rankings. ${ }^{8}$ Leverage is measured as market leverage $(A / M E)$, or book leverage $(A / B E)$; and earnings-to-price is the relation of net earnings (after interest and taxes) attributable to stockholders divided

\footnotetext{
${ }^{8}$ According to $\mathrm{F} \& \mathrm{~F}$, because estimates of market $\beta \mathrm{s}$ are more precise for portfolios than for stocks, based on the $M E$ and the stocks' pre- $\beta$ distributions together, we should form twenty-five portfolios and assign their estimated $\beta$ s to the individual stocks within each portfolio in the tests below.
}

162 Revista Brasileira de Finanças (Online), Rio de Janeiro, Vol. 14, N.2, June 2016 
by the market equity. The return momentum of an individual stock is the continuation of its short-term returns. We measure it as the cumulated returns over the past 2 to 12 months like Fama and French (1996), and updated every June as in F\&F:

$$
\operatorname{R.Mom}_{\cdot i, t-1}=\sum_{j=2}^{12} R_{i, t-j}
$$

\section{Results}

As stated before, for comparison purposes, we follow F\&F presentation closely.

Table 2 shows that portfolios formed on size and pre-ranking $\beta \mathrm{s}$, rather than just on size, widen the range of post-ranking $\beta$ s. Across all 25 size- $\beta$ portfolios, the post-ranking $\beta \mathrm{s}$ in panel 2.B range from 0.49 to 1.37 , an interval almost 3 times wider than the interval of $0.33(=1.05$ 0.72 ) obtained with size portfolios alone. ${ }^{9}$ While panel $2 . B$ suggests there is an inverse relation between post-ranking $\beta$ and size, panel 2.C does not relate size to pre-ranking $\beta$.

\footnotetext{
${ }^{9}$ We choose to ignore the portfolio $M E-3 \&$ High- $\beta$ while describing the big picture of Panel 2.B, given it is out of line with its neighbor cells.
}

@() Revista Brasileira de Finanças (Online), Rio de Janeiro, Vol. 14, N. 2, June 2016 


\section{Table 2}

Average Returns, Post-Ranking $\beta_{\mathrm{s}}$ and Average Size For Portfolios Formed on Size and then $\beta$ (July 1999 to June 2015)

\begin{tabular}{|c|c|c|c|c|c|c|}
\hline & All & Low- $\beta$ & $\beta-2$ & $\beta-3$ & $\bar{\beta} \beta-4$ & 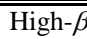 \\
\hline \multicolumn{7}{|c|}{ Panel 2.A: Average Monthly Returns (in Percent) } \\
\hline$\overline{\text { All }}$ & & 1.77 & 1.95 & 1.82 & 1.71 & 1.36 \\
\hline Small-ME & 1.99 & 2.41 & 2.90 & 1.66 & 1.61 & 1.21 \\
\hline ME-2 & 1.63 & 1.65 & 1.89 & 1.01 & 2.18 & 1.48 \\
\hline ME-3 & 2.03 & 2.11 & 1.89 & 2.41 & 1.49 & 2.18 \\
\hline ME-4 & 1.77 & 1.48 & 1.76 & 2.43 & 1.77 & 1.40 \\
\hline Large-ME & 1.23 & 1.24 & 1.32 & 1.58 & 1.52 & 0.50 \\
\hline \multicolumn{7}{|c|}{ Panel 2.B: Post-Ranking $\beta \mathrm{s}$} \\
\hline All & & 0.72 & 0.85 & 0.94 & 1.06 & 1.12 \\
\hline Small-ME & 1.05 & 0.78 & 1.02 & 1.02 & 1.12 & 1.37 \\
\hline ME-2 & 0.93 & 0.79 & 0.85 & 0.92 & 1.17 & 0.94 \\
\hline ME-3 & 1.10 & 0.76 & 0.96 & 1.20 & 1.18 & 1.40 \\
\hline ME-4 & 0.85 & 0.77 & 0.70 & 0.86 & 1.02 & 0.94 \\
\hline Large-ME & 0.72 & 0.49 & 0.71 & 0.67 & 0.82 & 0.95 \\
\hline \multicolumn{7}{|c|}{ Panel 2.C: Average Size $(\ln (\mathrm{ME}))$} \\
\hline All & & 7.10 & 7.14 & 7.05 & 7.13 & 6.98 \\
\hline Small-ME & 4.46 & 4.42 & 4.66 & 4.37 & 4.54 & 4.25 \\
\hline ME-2 & 6.20 & 6.19 & 6.06 & 6.18 & 6.31 & 6.24 \\
\hline ME-3 & 7.21 & 7.19 & 7.25 & 7.19 & 7.20 & 7.23 \\
\hline ME-4 & 8.11 & 8.14 & 8.09 & 8.13 & 8.15 & 8.06 \\
\hline Large-ME & 9.49 & 9.63 & 9.70 & 9.48 & 9.49 & 9.13 \\
\hline
\end{tabular}

Table 3 shows post-ranking average characteristics from July 1999 to June 2015 for portfolios formed from one-dimensional sorts of stocks on size or $\beta$. In panel 3.A, with portfolios formed on just size, we observe a negative (though not strict) relation between size and average return, and a positive relation between average return and $\beta$. Thus, a simple size sort is not enough to reject the CAPM prediction of a positive relation between $\beta \mathrm{s}$ and average returns. Unlike the size portfolios, the pre $\beta$ sorted portfolios are less supportive of the CAPM in panel 3.B. There is no positive relation between $\beta$ s and average returns, along the $\beta$-sorted portfolios. 
Table 3

Properties of Portfolios Formed on Size or Pre-Ranking $\beta$ (July 1999 to June 2015)

\begin{tabular}{lccccc}
\hline \hline & 1 & 2 & 3 & 4 & 5 \\
\hline \multicolumn{5}{c}{ Return } & \multicolumn{5}{c}{ Panel 3.A: Portfolios Formed on Size } & \\
Post- $\beta$ s & 1.99 & 1.63 & 2.03 & 1.77 & 1.23 \\
$\ln (\mathrm{ME})$ & 1.05 & 0.93 & 1.10 & 0.85 & 0.72 \\
$\ln (\mathrm{BM})$ & 4.46 & 6.20 & 7.21 & 8.11 & 9.49 \\
$\ln (\mathrm{A} / \mathrm{ME})$ & 0.34 & -0.07 & -0.30 & -0.46 & -0.62 \\
$\ln (\mathrm{A} / \mathrm{BE})$ & 1.51 & 0.85 & 0.66 & 0.50 & 0.27 \\
E/P dummy & 1.15 & 0.92 & 0.96 & 0.96 & 0.89 \\
E(+)/P & 0.41 & 0.20 & 0.15 & 0.13 & 0.10 \\
Momentum & 0.11 & 0.13 & 0.10 & 0.09 & 0.08 \\
\hline & 1.83 & 1.77 & 2.17 & 2.68 & 2.24 \\
\hline Return & Panel 3.B: Portfolios Formed on Pre-Ranking $\beta$ & 1.66 & 1.44 \\
Post- $\beta$ s & 1.73 & 2.03 & 1.78 & 1.08 & 1.11 \\
$\ln ($ ME) & 0.71 & 0.81 & 0.96 & 6.97 & 6.60 \\
$\ln (\mathrm{BM})$ & 7.53 & 7.20 & 7.10 & -0.11 & -0.11 \\
$\ln (\mathrm{A} / \mathrm{ME})$ & -0.38 & -0.21 & -0.27 & 0.88 & 0.98 \\
$\ln (\mathrm{A} / \mathrm{BE})$ & 0.57 & 0.66 & 0.72 & 0.98 & 1.10 \\
E/P dummy & 0.95 & 0.87 & 0.98 & 0.17 & 0.37 \\
E(+)/P & 0.13 & 0.13 & 0.19 & 0.12 & 0.08 \\
Momentum & 0.10 & 0.11 & 0.10 & 2.15 & 2.69 \\
\hline & 1.88 & 2.20 & 1.79 &
\end{tabular}

The puzzlingly evidence in Table 3 on the relation between $\square$ and average return for portfolios formed on size or $\beta$ alone is detailed in Table 2 . The second-pass $\beta$ sort does not produce the variation in average returns predicted by the CAPM. Although the post-ranking $\beta \mathrm{s}$ in panel 2.B increase along the row of each size quintile, average returns do not get higher in panel 2.A. Whilst, within the columns of Table 2, the average returns and $\beta$ s decrease with increasing size.

In sum, like in F\&F, Table 2 says that there is an inverse relation between size and average return, but controlling for size, there is no positive relation between $\beta$ and average return. In Table 2 and 3, we show that there is no reliable relation between $\beta$ and average returns. The variation in $\beta$ does not seem compensated in the average returns of stocks in Brazil during July 1999 - June 2015. Although not marked as in F\&F for the U.S., there are traces of a negative size-return relation. 
Varga, G., Brito, R. D.

\section{Table 4}

Average Slopes (t-statistics) from Month-by-Month Regressions of Stock Returns (July 1999 to June 2015)

\begin{tabular}{|c|c|c|c|c|c|c|c|c|}
\hline Row & $\beta$ & $\ln (\mathrm{ME})$ & $\ln (\mathrm{BM})$ & $\ln (\mathrm{A} / \mathrm{ME})$ & $\ln (\mathrm{A} / \mathrm{BE})$ & $\begin{array}{c}\text { E/P } \\
\text { Dummy }\end{array}$ & $\mathrm{E}(+) / \mathrm{P}$ & Momentum \\
\hline 1 & $\begin{array}{c}0.45 \\
(0.65)\end{array}$ & & & & & & & \\
\hline 2 & & $\begin{array}{c}-0.14 \\
(-1.47)\end{array}$ & & & & & & \\
\hline 3 & $\begin{array}{c}-0.15 \\
(-0.21)\end{array}$ & $\begin{array}{c}-0.14 \\
(-1.42)\end{array}$ & & & & & & \\
\hline 4 & & & $\begin{array}{c}0.44 \\
(2.54)\end{array}$ & & & & & \\
\hline 5 & $\begin{array}{c}0.08 \\
(0.10)\end{array}$ & & $\begin{array}{c}0.39 \\
(2.09)\end{array}$ & & & & & \\
\hline 6 & & $\begin{array}{c}-0.07 \\
(-0.70)\end{array}$ & $\begin{array}{c}0.36 \\
(2.07)\end{array}$ & & & & & \\
\hline 7 & & & & $\begin{array}{c}0.44 \\
(2.37)\end{array}$ & $\begin{array}{c}-0.29 \\
(-1.14)\end{array}$ & & & \\
\hline 8 & & $\begin{array}{c}-0.04 \\
(-0.45)\end{array}$ & & $\begin{array}{c}0.38 \\
(2.06)\end{array}$ & $\begin{array}{c}-0.27 \\
(-1.07)\end{array}$ & & & \\
\hline 9 & & & & & & $\begin{array}{c}-0.02 \\
(-0.04)\end{array}$ & $\begin{array}{c}2.26 \\
(1.54)\end{array}$ & \\
\hline 10 & & $\begin{array}{c}-0.14 \\
(-1.51)\end{array}$ & & & & $\begin{array}{c}-0.35 \\
(-0.95)\end{array}$ & $\begin{array}{c}1.53 \\
(1.07)\end{array}$ & \\
\hline 11 & & & $\begin{array}{c}0.33 \\
(1.96)\end{array}$ & & & $\begin{array}{l}-0.24 \\
(-0.6)\end{array}$ & $\begin{array}{c}1.36 \\
(1.01)\end{array}$ & \\
\hline 12 & & & & & & & & $\begin{array}{c}0.04 \\
(1.19)\end{array}$ \\
\hline 13 & $\begin{array}{c}0.09 \\
(0.12)\end{array}$ & $\begin{array}{c}-0.08 \\
(-0.81)\end{array}$ & $\begin{array}{c}0.37 \\
(2.00)\end{array}$ & & & & & $\begin{array}{c}0.05 \\
(1.63)\end{array}$ \\
\hline $14^{\#}$ & & & & & & & & $\begin{array}{c}0.10 \\
(2.61)\end{array}$ \\
\hline $15^{\#}$ & $\begin{array}{c}-0.06 \\
(-0.08)\end{array}$ & $\begin{array}{c}-0.15 \\
(-1.19)\end{array}$ & $\begin{array}{c}0.35 \\
(1.78) \\
\end{array}$ & & & & & $\begin{array}{c}0.11 \\
(2.71)\end{array}$ \\
\hline
\end{tabular}

As F\&F, we present our main results in Table 4. Using the Fama and MacBeth (1973) approach presented in section 2, each month, the cross-

166 Revista Brasileira de Finanças (Online), Rio de Janeiro, Vol. 14, N.2, June 2016 
section of stock returns is regressed on candidate explanatory variables. Then, the means of the slopes of the monthly regressions provide the tests of whether these explanatory variables were on average priced by the market during July 1999 - June 2015.

The first row of Table 4 shows that the market $\beta$ does not explain the cross-section of stock returns for 1999-2015. The average slope from the regressions of returns on $\beta$ alone is 0.45 and insignificant.

Like the average returns in Tables 2 and 3, the regressions estimates in Table 4 suggest that size helps explain the cross-section of stock returns in row 2 , however lacking convincing significance. The average slope from the regressions of returns on size alone is -0.14 , with a tstatistic of -1.47. This result is between Costa Jr. and Neves (2000) - who found size to be significant - and Braga and Leal (2003) or Antunes et al. (2006) - who have not found an important size effect in the Brazilian market. ${ }^{10}$

In the regressions of return on size and $\beta$ in row 3 , the size keeps its magnitude and significance, while the $\beta$ becomes negative, though still insignificant. The negative relation between size and average stock return persists with other explanatory variables in the regressions, but lose significance when variables related to "market imposed leverage" are included, in the following rows 4 to 8 of Table 4.

\footnotetext{
${ }^{10}$ Our time window overlaps with Antunes et al. (2006), and not with Costa Jr and Neves (2000) or Braga and Leal (2003). In Table 7 below, we discuss the stability of factors' premium estimates for subsamples of the period studied. For the period July 1999 - June 2007, closer to Antunes et al. (2006), our estimate of the size effect is more significant. Also see the Appendix for a discussion of Costa Jr. and Neves' (2000) results and a comparison with ours.
}

@.) Revista Brasileira de Finanças (Online), Rio de Janeiro, Vol. 14, N. 2, June 2016 


\section{Table 5}

Properties of Portfolios Formed on Book-to-Market Equity (BM) and Earnings-Price Ratio (E/P) (July 1999 to June 2015)

\begin{tabular}{lccccc}
\hline \hline & 1 & 2 & 3 & 4 & 5 \\
\hline Return & Panel 5.A: & Stocks & Sorted on & Book-to-Market Equity (BM) & \\
Post- $\beta$ s & 1.26 & 1.54 & 1.75 & 1.87 & 2.25 \\
$\ln (\mathrm{ME})$ & 0.90 & 0.97 & 0.88 & 0.88 & 1.02 \\
$\ln (\mathrm{BM})$ & 7.96 & 7.66 & 7.34 & 6.59 & 5.83 \\
$\ln (\mathrm{A} / \mathrm{ME})$ & -1.40 & -0.59 & -0.18 & 0.21 & 0.91 \\
$\ln (\mathrm{A} / \mathrm{BE})$ & -0.17 & 0.35 & 0.76 & 1.11 & 1.77 \\
E/P dummy & 1.22 & 0.94 & 0.94 & 0.91 & 0.86 \\
E(+)/P & 0.16 & 0.14 & 0.17 & 0.23 & 0.29 \\
R.Momentum & 0.06 & 0.09 & 0.11 & 0.12 & 0.13 \\
\hline & 2.20 & 2.28 & 2.01 & 1.93 & 2.31 \\
\hline Return & Panel 5.B: Stocks Sorted on Earnings-Price Ratio (E/P) & \\
Post- $\beta$ s & 1.49 & 1.23 & 1.75 & 1.77 & 2.27 \\
$\ln (\mathrm{ME})$ & 1.17 & 0.98 & 0.81 & 0.79 & 0.85 \\
$\ln (\mathrm{BM})$ & 6.15 & 7.65 & 7.76 & 7.37 & 6.67 \\
$\ln (\mathrm{A} / \mathrm{ME})$ & -0.05 & -0.55 & -0.48 & -0.25 & 0.17 \\
$\ln (\mathrm{A} / \mathrm{BE})$ & 1.19 & 0.35 & 0.35 & 0.64 & 1.10 \\
E/P dummy & 1.24 & 0.90 & 0.83 & 0.89 & 0.93 \\
E(+)/P & 0.81 & 0.00 & 0.00 & 0.00 & 0.00 \\
R.Momentum & 0.00 & 0.04 & 0.08 & 0.13 & 0.27 \\
\hline & 0.72 & 1.74 & 2.40 & 2.32 & 3.27 \\
\hline
\end{tabular}

There is a strong cross-sectional relation between average returns and book-to-market equity. The average slope of the monthly regressions of returns on $\ln (B M)$ alone is 0.44 , with a t-statistic of 2.54 in row 4; and such a significance is not due to the omission of market beta in row 5 . In Table 5, panel 5.A, we see the positive relation between average return and book-to-market equity from another perspective. Average returns rise from $1.26 \%$ for the lowest $B M$ portfolio to $2.25 \%$ for the highest $B M$ portfolio. This amplitude is greater than the observed for the size portfolios in Table 3, and the positive $B M$-return relation is strictly monotonic. These results are in line with Santos and Montezano (2011), who found that value stocks over-perform growth stocks in Brazil in the 1989-2009 period. 
As in F\&F, the book-to-market relation seems stronger than the size effect, alone and jointly. In row 6 of Table 4, when both $M E$ and $B M$ are included in the analysis, they become individually less significant because of their correlation. Both coefficients suffer meaningful reductions in magnitude and significance, with the size effect diminishing more.

Table 6 illustrates the two-dimensional variation in average returns that results when the 5 size quintiles of firms are each subdivided into 5 portfolios according to $B M$. Within a size quintile, average returns tend to increase with $B M$ (with the exception of ME-2). Similarly, within a $B M$ quintile, average returns tend to decrease with the increase in size. This average return matrix clarifies the conclusion from Table 4 that, controlling for size, book-to-market equity captures variation in average returns; and controlling for book-to-market equity, size captures variation in average returns (though weakly than in F\&F).

\section{Table 6}

Average Monthly Returns on Portfolios Formed on Size and Book-to-Market Equity (July 1999 to June 2015)

\begin{tabular}{lcccccc}
\hline \hline & \multicolumn{7}{c}{ Book-to-Market (BM) Portfolios } \\
\cline { 2 - 7 } & All & Low & 2 & 3 & 4 & High \\
\hline All & & 1.55 & 1.26 & 1.66 & 1.92 & 2.31 \\
Small-ME & 1.99 & 1.48 & 1.76 & 1.38 & 2.14 & 3.42 \\
ME-2 & 1.63 & 1.73 & 1.51 & 1.51 & 1.78 & 1.64 \\
ME-3 & 2.03 & 1.57 & 1.25 & 2.64 & 1.95 & 2.74 \\
ME-4 & 1.77 & 1.63 & 1.11 & 1.72 & 2.24 & 2.21 \\
Large-ME & 1.23 & 1.36 & 0.64 & 1.03 & 1.54 & 1.57 \\
\hline
\end{tabular}

The relation between $\ln (M E)$ and $\ln (B M)$ for individual stocks in Brazilian data is evident from Table 3.A. The correlation of -0.47 is almost twice the measure documented by $F \& F$, and clearly affects the regressions in Table 4. The inclusion of $\ln (B M)$ moves the average slope on $\ln (M E)$ from $-0.14(\mathrm{t}=-1.42)$ in the univariate regressions to $-0.07(\mathrm{t}=$ $-0.70)$ in the bivariate regressions. On the other hand, by including $\ln (M E)$ in the regressions lowers the average slope of $\ln (B M)$ from 0.44 
to 0.36 (still a 2.07 standard errors from 0 ). The $5 \times 5$ matrix in Table 6 farther documents that, (a) book-to-market equity captures important variation in the cross-section of average returns after controlling for size, and (b) average returns are not that related to size after controlling for $B M$ for the July 1999 - June 2015 period. Thus, we are driven to conclude that size is not that important. However, for comparison purposes with international evidence, we choose to keep an eye on it.

In row 7 of Table 4 , we see that market leverage $(A / M E)$ is significant in explaining average returns, although book leverage $(A / B E)$ is not. F\&F got significant coefficients for both measures, of approximately the same magnitude and opposite signs, supporting the claim that it is not leverage that matters, but the $B M(\ln (B M)=$ $\ln (B E / M E)=\ln (A / M E)-\ln (A / B E))$, which captures a "relative-distress" effect. The results in row 7 do not confirm such claim, but do not reject it either. The fact that market leverage increases expected return, while book leverage does not decrease it, means that leverage matters and it is better measured by market imposed leverage. In Table 5, panel 5.A, we can confirm that market leverage and book-to-market are highly correlated, deserving similar interpretation. ${ }^{11}$

In row 8 , we see that if size and leverages are used together, size recedes and market leverage becomes smaller but still significant, in a pattern similar to when size and book-to-market are employed jointly in row 6.

In row 9 of Table 4 , we see that average returns increase with positive $E / P$, but the coefficient for negative $E / P$ (i.e., the $E / P$ Dummy $=$ 1 if $E / P<0$ ) is almost zero. The fact that Brazilian firms with negative earning did not offer significantly higher average returns is also presented in Table 5, row "Return" of panel 5.B, where the U-shape relation described by F\&F (in their Table IV for the U.S.) is not that convincing. Although average returns decline from the negative $E / P$ portfolio to the second lowest $E / P$ portfolio, this decrease is from $1.49 \%$ to $1.23 \%$ only, and average returns then increase monotonically, reaching $2.27 \%$ per month for the highest $E / P$ portfolio. Like $\mathrm{F} \& \mathrm{~F}$, we find that the higher returns of negative $E / P$ are better captured by their size, given the

\footnotetext{
${ }^{11}$ The correlation between $\ln (B M)$ and $\ln (A / M E)$ is close to 0.80 . 
negative $E / P$ group is composed of the smallest firms on average, as shown in row " $\ln (M E)$ " of panel 5.B.

Rows 10 and 11 of Table 4 show that the average slopes for $\ln (M E)$ or $\ln (B M)$ in the regressions that include earnings are similar to those in the regressions of average returns on $\ln (M E)$ or $\ln (B M)$ alone, while the earnings effects lessen considerably. As pointed by $F \& F$, these suggest that the relation between earnings and average return is due to the omission of $\ln (M E)$ or $\ln (B M)$. The concentration of negative $E / P$ in the smallest size quintile is shown in row "E/P Dummy" of panel 3.A. The positive correlation between $E(+) / P$ and $B M$ is clear in Table $5 .{ }^{12}$ Like $(A / M E)$ and $B M, E(+) / P$ is a measure of market imposed discount for relative-distress risk.

Finally, rows 12 to 15 examine if the stock's momentum correlates with expected return. The momentum importance is not that convincing in row 12 , but when simultaneously controlled for $\beta, \ln (M E)$ and $\ln (B M)$ in row 13, its significance increases. If the sample studied is restrained to stocks with more than 5 trades in the month, the momentum becomes significant in row 14, and is the most significant characteristic in the multiple regression of row $15 .{ }^{13}$ The comparison of rows 12-13 with 1415 thus suggests that to turn stocks' momentum into return prediction some degree of liquidity is necessary.

This is an interesting finding, given previous papers that analyzed the continuation of short-term returns (i.e. momentum) together with long-term reversal, like Bonomo and Dall'Agnol (2003) and Kimura (2003), found evidence of reversals, but not of continuations.

The effect of stocks' momentum on the cross-section of returns deserves additional comments. The inspection of Tables 3 and 5 do not reveal any obvious relation between momentum and the quintiles of size,

\footnotetext{
${ }^{12}$ When looking at panel 4.B, ignore the first column of negative $E / P$ firms.

${ }^{13}$ As we will see below, in Tables 8 and 9, except for this $\ln (B M)$ versus momentum change in relative importance, the other characteristics importance does not change much as we turn from our main (most comprehensive) sample to the sub-sample of more liquid stocks (or to other sub-samples), the reason why it is not worth showing all specifications' estimates to various sub-samples.
}

$@$ Revista Brasileira de Finanças (Online), Rio de Janeiro, Vol. 14, N. 2, June 2016 
$\beta$, or book-to-market characteristics, but a positive correlation with the $E(+) / P$ - their correlation is close to 0.15 . The momentum relation with $\ln (M E)$ and $\ln (B M)$ is low and, as we can also guess from the comparison of rows 6 and 13 in Table 4, the inclusion of momentum does not affect the importance of size and book-to-market in predicition of crosssectional returns.

Summing up, book-to-market and momentum have the most significant premiums. While they both seem to matter in a multicharacteristic explanation of the cross-section of returns, their relative importance varies depending on the sample liquidity requirement. The book-to-market characteristic pays a positive and significant premium, but loses some significance in a multi-characteristic model due to its correlation with beta and size. The momentum also pays a positive premium that becomes more important within liquid stocks, and seems less related to the market $\beta$, size or book-to-market. The size shows vestiges of a negative premium, but does not add much in relation to book-to-market. Finally, the market $\beta$ does not seem to explain the crosssection of stock returns for the period from July 1999 to June 2015, alone or jointly with other characteristics.

As outlined in the introduction, if these characteristics are proxies for fundamental risk, we might expect them to continually pay premiums. If, on the other hand, return premiums arose because of mispricing, we might expect these excess returns not to generalize along time as investors arbitrate them.

To check if these patterns holds in general, Table 7 presents the average FM slopes for two equal subperiods (July 1999-June 2007 and July 2007-June 2015) from seven cross-section regressions of stock returns on: (a) $\beta$ only, (b) $\ln (M E)$ only, (c) $\ln (B M)$ only, (d) $\ln (M E)$ and $\ln (B M)$, (e) $\beta, \ln (M E)$ and $\ln (B M)$, (f) momentum only, and $(\mathrm{g}) \beta$, $\ln (M E), \ln (B M)$ and momentum. The average returns on the equalweighted index (E.W.I.), Ibovespa (the BOVESPA index) and the interbank deposit rate (C.D.I.) are also shown for reference. ${ }^{14}$

\footnotetext{
${ }^{14}$ The C.D.I. is a short term interest rate used as a reference of riskless rate in the Brazilian domestic market.

172 Revista Brasileira de Finanças (Online), Rio de Janeiro, Vol. 14, N.2, June 2016
} 


\section{Table 7}

Subperiod Average Monthly Returns on the Ibovespa and Subperiod Means of the Intercepts and Slopes from the Monthly FM Cross-Sectional Regressions

\begin{tabular}{|c|c|c|c|c|c|c|c|c|c|}
\hline \multirow[b]{2}{*}{ Variable } & \multicolumn{3}{|c|}{ 7/1999 - 6/2015 (192 Mos.) } & \multicolumn{3}{|c|}{ 7/1999 - 6/2007 (96 Mos.) } & \multicolumn{3}{|c|}{ 7/2007 - 6/2015 (96 Mos.) } \\
\hline & Mean & Std. Dev. & $\mathrm{t}(\mathrm{Mn})$ & Mean & Std. Dev. & $\mathrm{t}(\mathrm{Mn})$ & Mean & Std. Dev. & $\mathrm{t}(\mathrm{Mn})$ \\
\hline \multicolumn{10}{|c|}{ Benchmark Returns } \\
\hline E.W.I. & 1.84 & 6.64 & 3.85 & 3.37 & 6.77 & 4.88 & 0.31 & 6.17 & 0.50 \\
\hline Ibovespa & 1.09 & 7.84 & 1.93 & 1.98 & 8.37 & 2.31 & 0.21 & 7.21 & 0.28 \\
\hline C.D.I. & 1.10 & 0.34 & 44.55 & 1.38 & 0.24 & 56.52 & 0.82 & 0.15 & 54.73 \\
\hline \multicolumn{10}{|c|}{$\mathrm{R}_{\mathrm{it}}=\lambda_{\mathrm{t}}^{0}+\lambda^{\beta}{ }_{\mathrm{t}} \beta_{\mathrm{it}}+\mathrm{e}_{\mathrm{it}}$} \\
\hline$\lambda^{0}$ & 1.31 & 7.59 & 2.39 & 1.23 & 9.00 & 1.34 & 1.39 & 5.90 & 2.31 \\
\hline$\lambda^{\beta}$ & 0.45 & 9.60 & 0.65 & 1.96 & 10.94 & 1.75 & -1.06 & 7.81 & -1.33 \\
\hline \multicolumn{10}{|c|}{$\mathrm{R}_{\mathrm{it}}=\lambda_{\mathrm{t}}^{0}+\lambda_{\mathrm{t}}^{\mathrm{ME}} \ln \left(\mathrm{ME}_{\mathrm{it}}\right)+\mathrm{e}_{\mathrm{it}}$} \\
\hline$\lambda^{0}$ & 2.65 & 11.64 & 3.16 & 5.15 & 12.59 & 4.01 & 0.15 & 10.06 & 0.15 \\
\hline$\lambda^{\mathrm{ME}}$ & -0.14 & 1.28 & -1.47 & -0.30 & 1.44 & -2.07 & 0.03 & 1.09 & 0.29 \\
\hline \multicolumn{10}{|c|}{$\mathrm{R}_{\mathrm{it}}=\lambda_{\mathrm{t}}^{0}+\lambda_{\mathrm{t}}^{\mathrm{BM}} \ln \left(\mathrm{BM}_{\mathrm{it}}\right)+\mathrm{e}_{\mathrm{it}}$} \\
\hline$\lambda^{0}$ & 1.72 & 6.36 & 3.75 & 3.01 & 7.06 & 4.17 & 0.43 & 5.29 & 0.79 \\
\hline$\lambda^{\mathrm{BM}}$ & 0.44 & 2.37 & 2.54 & 0.88 & 2.78 & 3.09 & -0.01 & 1.79 & -0.04 \\
\hline \multicolumn{10}{|c|}{$\mathrm{R}_{\mathrm{it}}=\lambda_{\mathrm{t}}^{0}+\lambda_{\mathrm{t}}^{\mathrm{ME}} \ln \left(\mathrm{ME}_{\mathrm{it}}\right)+\lambda_{\mathrm{t}}^{\mathrm{BM}} \ln \left(\mathrm{BM}_{\mathrm{it}}\right)+\mathrm{e}_{\mathrm{it}}$} \\
\hline$\lambda^{0}$ & 2.18 & 12.03 & 2.51 & 4.32 & 13.42 & 3.15 & 0.04 & 10.10 & 0.04 \\
\hline$\lambda^{\mathrm{ME}}$ & -0.07 & 1.34 & -0.70 & -0.19 & 1.54 & -1.19 & 0.05 & 1.10 & 0.47 \\
\hline$\lambda^{\mathrm{BM}}$ & 0.36 & 2.40 & 2.07 & 0.66 & 2.90 & 2.23 & 0.05 & 1.71 & 0.30 \\
\hline \multicolumn{10}{|c|}{$\mathrm{R}_{\mathrm{it}}=\lambda_{\mathrm{t}}^{0}+\lambda_{\mathrm{t}}^{\beta} \beta_{\mathrm{it}}+\lambda^{\mathrm{ME}}{ }_{\mathrm{t}} \ln \left(\mathrm{ME}_{\mathrm{it}}\right)+\lambda^{\mathrm{BM}}{ }_{\mathrm{t}} \ln \left(\mathrm{BM}_{\mathrm{it}}\right)+\mathrm{e}_{\mathrm{it}}$} \\
\hline$\lambda^{0}$ & 2.43 & 13.77 & 2.44 & 3.36 & 15.66 & 2.10 & 1.50 & 11.59 & 1.26 \\
\hline$\lambda^{\beta}$ & -0.16 & 10.66 & -0.21 & 0.79 & 12.68 & 0.61 & -1.12 & 8.10 & -1.35 \\
\hline$\lambda^{\mathrm{ME}}$ & -0.07 & 1.38 & -0.75 & -0.15 & 1.57 & -0.93 & 0.00 & 1.17 & 0.00 \\
\hline$\lambda^{\mathrm{BM}}$ & 0.34 & 2.56 & 1.83 & 0.61 & 3.21 & 1.86 & 0.07 & 1.66 & 0.39 \\
\hline \multicolumn{10}{|c|}{$\mathrm{R}_{\mathrm{it}}=\lambda_{\mathrm{t}}^{0}+\lambda^{\text {Mom. }}{ }_{\mathrm{t}}$ R.Mom $_{\text {it }}+\mathrm{e}_{\mathrm{it}}$} \\
\hline$\lambda^{0}$ & 1.76 & 6.51 & 3.75 & 3.16 & 7.16 & 4.33 & 0.36 & 5.47 & 0.65 \\
\hline$\lambda^{\text {Mom. }}$ & 0.04 & 0.45 & 1.19 & 0.02 & 0.44 & 0.37 & 0.06 & 0.46 & 1.28 \\
\hline \multicolumn{10}{|c|}{$\mathrm{R}_{\mathrm{it}}=\lambda_{\mathrm{t}}^{0}+\lambda_{\mathrm{t}}^{\beta} \beta_{\mathrm{it}}+\lambda_{\mathrm{t}}^{\mathrm{ME}} \ln \left(\mathrm{ME}_{\mathrm{it}}\right)+\lambda^{\mathrm{BM}}{ }_{\mathrm{t}} \ln \left(\mathrm{BM}_{\mathrm{it}}\right)+\lambda^{\mathrm{Mom} .}{ }_{\mathrm{t}}$ R.Mom ${ }_{\mathrm{it}}+\mathrm{e}_{\mathrm{it}}$} \\
\hline$\lambda^{0}$ & 2.27 & 13.93 & 2.26 & 3.03 & 15.92 & 1.87 & 1.52 & 11.63 & 1.28 \\
\hline$\lambda^{\beta}$ & 0.09 & 10.78 & 0.12 & 1.13 & 12.91 & 0.86 & -0.94 & 8.04 & -1.15 \\
\hline$\lambda^{\mathrm{ME}}$ & -0.08 & 1.39 & -0.81 & -0.14 & 1.60 & -0.88 & -0.02 & 1.16 & -0.16 \\
\hline$\lambda^{\mathrm{BM}}$ & 0.37 & 2.55 & 2.00 & 0.60 & 3.20 & 1.85 & 0.13 & 1.66 & 0.78 \\
\hline$\lambda^{\text {Mom. }}$ & 0.05 & 0.43 & 1.63 & 0.04 & 0.43 & 0.84 & 0.06 & 0.42 & 1.46 \\
\hline
\end{tabular}


Recalling equation (5) in section 2, the intercept is the return on a portfolio in which the weighted averages of the explanatory variables are 0 . In our sample, the intercept is weighted toward firms with no sensitivity to the market portfolio $(\beta=0)$, small in size $(M E$ is in millions of BRL, so $\ln (M E)=0$ implies $M E=R \$ 1$ million), with medium-high book-to-market ratios (Table 4 indicates that $\ln (B M)=0$ is between the $3 \mathrm{rd}$ and the 4rd quintiles), and zero momentum. Thus, for example, if small stocks had higher average returns in the whole sample, and $\ln (M E)=0$ is for small firms, the average intercept is above the returns on the E.W.I and Ibovespa, and vice-versa. ${ }^{15}$

Our results in Table 7 differ from F\&F, who found that size and book-to-market premiums kept their negative and positive signals respectively in both subperiods. We find that the size premium, which is negative and significant in the earlier subperiod, becomes positive and insignificant in the later subperiod. The significant positive book-tomarket premium in the earlier subperiod is also turned into an almost zero coefficient in the later subperiod. For the market $\beta$, the small positive and insignificant $\beta$ 's average premium for the overall period is revealed to be the combination of a positive premium for the earlier subperiod and a negative premium in the later subperiod. ${ }^{16}$ Different from the other characteristics, the momentum is less significant in the earlier subperiod and more significant in the later.

With the caveat that inferences for such short subperiods lack power, the weak effects of all the caracteristics in one out of two sub-periods, and the change in signal of prices of risk, undermine the hyphotesis that those caracteristics are proxies for sistematic risk factors that consistently explain the cross-section of average stock returns.

A comparison to the Brazilian literature also seem to indicate some instability of these premiums in Brazil. For the period from March 1988 to February 1996, not included in our main sample, Costa Jr. and Neves (2000) used a Seemingly Unrelated Regression of eight portfolios'

\footnotetext{
${ }^{15}$ The Ibovespa is a liquidity based index that tends to overweight large firms.

${ }^{16}$ The fact that the $\beta$ 's market price of risk seems insignificant and negative has already been documented in Brazil, by Hagler and Brito (2006) and Murakoshi and Brito (2009) among others.

174 Revista Brasileira de Finanças (Online), Rio de Janeiro, Vol. 14, N.2, June 2016
} 
returns on the portfolios' $\beta, E / P$, size and $B M$. They found that all these three characteristcs were individually and jointly significant at the $5 \%$ level with the same signs of F\&F's Table III (the equivalent of our Table 4$)$, and that the market $\beta$ price of risk $\left(\lambda^{\beta}\right)$ was the most important factor in their sample. Instead of analyzing individual stocks, Braga and Leal (2003) studied 16 portfolios of Brazilian stocks sorted by size and $B M$ (4x4 portfolios) for the period July 1991-June 1998 and confirmed that high $B M$ stocks had greater average returns and Sharpe ratios than low $B M$ ones, but did not find any size effect.

Alternatively, to more convincingly dismiss the market $\beta$ and size as factor premiums, and to allow the reader fully compare the Brazilian case with $\mathrm{F} \& \mathrm{~F}$, we look for the continuation of these premiums into the longer 27-year period July 1988-June 2015 in another data base in the Appendix. As described in section 3 (Data), we exclude stocks that have less than 36 contiguous observations. And, given the Brazilian inflation was much higher and variable before 1999, for comparability along different inflation regimes, we choose to work with real variables, i.e., constant prices instead of current nominal prices. Basically, the results from Tables A.1 to A. 4 confirm that the size and market $\beta$ are not important to explain the cross-section of expected returns in Brazil. Although they are significant in single characteristic regressions for the sub-period July 1999-June 2007, given the high correlation between the market $\beta$ and size, neither variable is individually significant when they are used together. ${ }^{17}$

Finally, we attempt a first glance at the issues of liquidity and government-controlled firms. Liquidity and state governance risk are characteristics of concern to investors in Brazil. Liquidity here has a simple uptake, we just delete thinly traded stocks based on the number of trades per day, therefore excluding returns that are noisier and economically less important. For example, if growth stocks are more liquid (or less government-controlled) than value stocks, the value

\footnotetext{
${ }^{17}$ If we alternatively simply include every stock to which we have returns in the month, we estimate much more significant $\lambda^{\beta}$ and $\lambda^{M E}$ for this earlier July 1988-June 1999 sub-period, similar Costa Jr. and Neves (2000). These results can be provided upon request.
}

@.) Revista Brasileira de Finanças (Online), Rio de Janeiro, Vol. 14, N. 2, June 2016 
premium may in part reflect a compensation for the lower liquidity (or for greater government-management inefficiency) of value firms. Are the book-to-market, momentum or size premiums cross-sectionally correlated with liquidity or state-control?

\section{Table 8}

Average Monthly Returns on Portfolios Formed on Size and Book-to-Market Equity (July 1999 to June 2015) for Subsamples

\begin{tabular}{|c|c|c|c|c|c|c|}
\hline & \multicolumn{6}{|c|}{ Book-to-Market (BM) Portfolios } \\
\hline & All & Low & 2 & 3 & 4 & High \\
\hline \multicolumn{7}{|c|}{ 8.A. Full sample } \\
\hline All & & 1.55 & 1.26 & 1.66 & 1.92 & 2.31 \\
\hline Small-ME & 1.99 & 1.48 & 1.76 & 1.38 & 2.14 & 3.42 \\
\hline ME-2 & 1.63 & 1.73 & 1.51 & 1.51 & 1.78 & 1.64 \\
\hline ME-3 & 2.03 & 1.57 & 1.25 & 2.64 & 1.95 & 2.74 \\
\hline ME-4 & 1.77 & 1.63 & 1.11 & 1.72 & 2.24 & 2.21 \\
\hline Large-ME & 1.23 & 1.36 & 0.64 & 1.03 & 1.54 & 1.57 \\
\hline \multicolumn{7}{|c|}{ 8.B. Only companies with more than 5 trades in the month } \\
\hline All & & 1.61 & 1.00 & 1.77 & 2.21 & 1.84 \\
\hline Small-ME & 1.98 & 2.19 & 1.08 & 1.45 & 3.14 & 2.31 \\
\hline ME-2 & 1.60 & 1.74 & 0.99 & 1.70 & 2.10 & 1.54 \\
\hline ME-3 & 2.00 & 1.58 & 1.30 & 2.77 & 2.07 & 2.56 \\
\hline ME-4 & 1.51 & 1.56 & 0.11 & 1.62 & 2.67 & 1.51 \\
\hline Large-ME & 1.18 & 0.99 & 1.42 & 1.48 & 0.99 & 1.06 \\
\hline \multicolumn{7}{|c|}{ 8.C. Only non-government-controlled companies } \\
\hline All & & 1.61 & 1.33 & 1.50 & 1.98 & 2.38 \\
\hline Small-ME & 1.96 & 1.65 & 1.68 & 1.53 & 1.80 & 3.14 \\
\hline ME-2 & 1.59 & 1.85 & 1.53 & 1.19 & 1.55 & 1.84 \\
\hline ME-3 & 2.10 & 1.69 & 1.40 & 2.09 & 2.60 & 2.91 \\
\hline ME-4 & 1.84 & 1.54 & 1.47 & 1.65 & 2.28 & 2.29 \\
\hline Large-ME & 1.26 & 1.36 & 0.58 & 0.97 & 1.66 & 1.79 \\
\hline \multicolumn{7}{|c|}{ 8.D. Only non-government-controlled companies with more than 5 trades in the month } \\
\hline All & & 1.65 & 1.01 & 1.59 & 1.90 & 2.47 \\
\hline Small-ME & 1.98 & 2.42 & 1.23 & 1.39 & 2.59 & 2.38 \\
\hline ME-2 & 1.71 & 1.46 & 1.08 & 1.85 & 1.61 & 2.67 \\
\hline ME-3 & 1.83 & 1.29 & 1.50 & 2.17 & 1.93 & 2.67 \\
\hline ME-4 & 1.62 & 1.18 & 0.31 & 1.70 & 2.30 & 2.62 \\
\hline Large-ME & 1.28 & 1.77 & 0.85 & 0.82 & 1.07 & 1.97 \\
\hline
\end{tabular}

176 Revista Brasileira de Finanças (Online), Rio de Janeiro, Vol. 14, N.2, June 2016 
The Tables 8 and 9 show that liquidity does not seem to change the pattern of returns regarding size. However, Table 8 lightly indicates that liquidity reduces the value premium - average returns of high $B M$ are lower and of low $B M$ are higher -, supporting the covariance hypothesis with liquidity risk.

\section{Table 9}

Subperiod Means of the Intercept and Slopes from the Monthly FM Cross-Sectional Regression $R_{i t}=\lambda_{t}^{0}+\lambda_{t}^{M E} \ln \left(M E_{i t}\right)+\lambda_{t}^{B M} \ln \left(B M_{i t}\right)+\lambda_{t}^{M o m} \cdot$ R.Mom $_{i t}+e_{i t}$

\begin{tabular}{|c|c|c|c|c|c|c|c|c|c|}
\hline \multirow[b]{2}{*}{ Variable } & \multicolumn{3}{|c|}{ 7/1999 - 6/2015 (192 Mos.) } & \multicolumn{3}{|c|}{ 7/1999 - 6/2007 (96 Mos.) } & \multicolumn{3}{|c|}{ 7/2007 - 6/2015 (96 Mos.) } \\
\hline & Mean & Std. Dev. & $\mathrm{t}(\mathrm{Mn})$ & Mean & Std. Dev. & $\mathrm{t}(\mathrm{Mn})$ & Mean & Std. Dev. & $\mathrm{t}(\mathrm{Mn})$ \\
\hline \multicolumn{10}{|c|}{ 9.A. Full sample } \\
\hline$\lambda^{0}$ & 2.27 & 13.93 & 2.26 & 3.03 & 15.92 & 1.87 & 1.52 & 11.63 & 1.28 \\
\hline$\lambda^{\beta}$ & 0.09 & 10.78 & 0.12 & 1.13 & 12.91 & 0.86 & -0.94 & 8.04 & -1.15 \\
\hline$\lambda^{\mathrm{ME}}$ & -0.08 & 1.39 & -0.81 & -0.14 & 1.60 & -0.88 & -0.02 & 1.16 & -0.16 \\
\hline$\lambda^{\mathrm{BM}}$ & 0.37 & 2.55 & 2.00 & 0.60 & 3.20 & 1.85 & 0.13 & 1.66 & 0.78 \\
\hline$\lambda^{\text {Mom. }}$ & 0.05 & 0.43 & 1.63 & 0.04 & 0.43 & 0.84 & 0.06 & 0.42 & 1.46 \\
\hline \multicolumn{10}{|c|}{ 9.B. Only companies with more than 5 trades in the month } \\
\hline$\lambda^{0}$ & 2.66 & 16.91 & 2.18 & 2.95 & 18.42 & 1.57 & 2.38 & 15.34 & 1.52 \\
\hline$\lambda^{\beta}$ & -0.06 & 10.39 & -0.08 & 1.35 & 11.44 & 1.16 & -1.47 & 9.07 & -1.59 \\
\hline$\lambda^{\mathrm{ME}}$ & -0.15 & 1.71 & -1.19 & -0.21 & 1.97 & -1.02 & -0.09 & 1.42 & -0.61 \\
\hline$\lambda^{\mathrm{BM}}$ & 0.35 & 2.71 & 1.78 & 0.66 & 3.40 & 1.90 & 0.03 & 1.72 & 0.19 \\
\hline$\lambda^{\text {Mom. }}$ & 0.11 & 0.55 & 2.71 & 0.09 & 0.56 & 1.55 & 0.13 & 0.54 & 2.28 \\
\hline \multicolumn{10}{|c|}{ 9.C. Only non-government-controlled companies } \\
\hline$\lambda^{0}$ & 1.40 & 13.15 & 1.47 & 1.83 & 14.45 & 1.24 & 0.97 & 11.78 & 0.80 \\
\hline$\lambda^{\beta}$ & 0.50 & 10.61 & 0.65 & 1.60 & 12.92 & 1.21 & -0.60 & 7.55 & -0.78 \\
\hline$\lambda^{\mathrm{ME}}$ & 0.01 & 1.39 & 0.06 & -0.01 & 1.55 & -0.04 & 0.02 & 1.22 & 0.15 \\
\hline$\lambda^{\mathrm{BM}}$ & 0.46 & 2.80 & 2.29 & 0.74 & 3.53 & 2.05 & 0.18 & 1.77 & 1.02 \\
\hline$\lambda^{\text {Mom. }}$ & 0.05 & 0.47 & 1.32 & 0.03 & 0.51 & 0.49 & 0.06 & 0.43 & 1.47 \\
\hline \multicolumn{10}{|c|}{ 9.D. Only non-government-controlled companies with more than 5 trades in the month } \\
\hline$\lambda^{0}$ & 2.88 & 18.68 & 2.14 & 3.24 & 18.93 & 1.68 & 2.52 & 18.52 & 1.34 \\
\hline$\lambda^{\beta}$ & -0.53 & 12.24 & -0.60 & 0.47 & 13.91 & 0.33 & -1.52 & 10.28 & -1.45 \\
\hline$\lambda^{\mathrm{ME}}$ & -0.11 & 1.86 & -0.81 & -0.12 & 2.04 & -0.58 & -0.10 & 1.66 & -0.58 \\
\hline$\lambda^{\mathrm{BM}}$ & 0.48 & 3.05 & 2.20 & 0.92 & 3.83 & 2.36 & 0.05 & 1.90 & 0.24 \\
\hline$\lambda^{\text {Mom. }}$ & 0.10 & 0.58 & 2.48 & 0.08 & 0.61 & 1.29 & 0.13 & 0.56 & 2.26 \\
\hline
\end{tabular}


Regarding the relation of government-control and average returns, with the exclusion of government-controlled firms in panel 8.C, we see little increases in most of the portfolios average returns, instead of a decrease in premium predicted by the covariance hypothesis with government-mismanagement risk. Basically this result reveals that government-controlled companies rewarded stockholder below the average of firms with similar size and book-to-market. Because government-controlled firms usually have larger size and higher book-tomarket, their exclusion should decrease the importance of the size premium and increases the importance of the value premium. That is something we do not grasp from Table 8, but that we sense from the variation of $\lambda^{M E}$ and $\lambda^{B M}$ significances in Table 9 (comparing panels 9.A and 9.C).

More interesting in Table 9 is that, going in the opposite direction of the value premium, the momentum premium considerably strengthens in the more liquid subsample (comparing panels 9.A and 9.B), suggesting it needs investors' active interest on the stock to emerge.

\section{Conclusion}

In this article, we have followed F\&F closely to make sense of how (dis)similar are the Brazilian expected stock returns from the U.S. referential. Size, book-to-market, leverage, earnings-to-price and momentum were measured for the individual stocks and tested as individual observable characteristics that explain the cross section of returns.

Similar to the U.S., where F\&F found that book-to-market is the main factor explaining returns, we found that this factor seems to matter in Brazil. Although the book-to-market showed some power alone, or jointly with other variables, in the more recent period, it faded away. The market $\beta$ and size were insignificant in most of the FM regressions, not playing a convincing role in explaining the cross section of expected returns. As relevant as the book-to-market, is the momentum premium 
that showed similar importance, being more or less significant depending on the sample period and liquidity requirement.

Given our studied sample only has 16 years, we are aware that inferences about the magnitude of slopes may lack power. As next steps in this agenda, we suggest a more detailed analysis of the momentum, book-to-market and size effects as common risk factors mimicked by portfolios, like in Fama and French (1993, 1996). Whether it is the characteristics or the covariance structure of returns that explains the cross-sectional variation in stock returns, as suggested in Daniel and Titman (1997), this is something relevant to debate in Brazil. 


\section{References}

Antunes, Gustavo; Bressen, Aureliano; Lamounier, Wagner. 2006. Análise do efeito tamanho nos retornos das ações de empresas listadas na Bovespa. Revista de Contabilidade e Finanças da USP, 40, $87-101$.

Black, Fisher, Jensen, Michael, Scholes, Myron, 1972. The Capital Asset Pricing Model: Some Empirical Tests. In Jensen, M., editor, Studies in the Theory of Capital Markets, Praeger Publishers Inc.

Bonomo, Marco; \& Dall'Agnol, Ivana. 2003. Retornos anormais e estratégias contrárias. Revista Brasileira de Finanças, 1(2), 165-215.

Braga, C.; \& Leal, Ricardo. 2003. Ações de valor e crescimento nos anos 1990. In Bonomo, M., editor, Finanças Aplicadas ao Brasil. Rio de Janeiro: Editora FGV.

Campbell, John. 2014. Empirical Asset Pricing: Eugene Fama, Lars Peter Hansen, and Robert Shiller. Scandinavian Journal of Economics, 116, 593-634.

Cochrane, John. 2005. Asset Pricing: revised edition. Princeton University Press: New Jersey.

Cochrane, John. 2008. Introduction for Gene Fama. In: American Finance Association, "The History of the Theory and Evidence on the Efficient Markets Hypothesis".

Costa Jr., Newton; \& Neves, Myrian. 2000. Variáveis fundamentalistas e os retornos das ações. Revista Brasileira de Economia, 54, n.1, 123137.

De Bondt, Werner; \& Thaler, Richard. 1985. Does the stock market overreact? Journal of Finance, 40, 793-805.

Daniel, Kent; \& Titman, Sheridan. 1997. Evidence on characteristics of cross-sectional variation in stock returns. Journal of Finance, 52 (1), $1-33$. 
Fama, Eugene F.; \& French, Kenneth R. 1992. The cross-section of expected stock returns. Journal of Finance, 47 (2), 427-465.

Fama, Eugene F.; \& French, Kenneth R. 1993. Common risk factors in the returns on stocks and bonds. Journal of Financial Economics, 33, $3-56$.

Fama, Eugene F.; \& French, Kenneth R. 1995. Size and book to market factors in earnings returns. Journal of Finance, 50 (1), 131-155.

Fama, Eugene F.; \& French, Kenneth R. 1996. Multifactor explanations of asset pricing anomalies. Journal of Finance, 51, 55-84.

Fama, Eugene F.; \& French, Kenneth R. 1998. Value versus growth: The international evidence. Journal of Finance, 51 (5), 1975-1999.

Fama, Eugene F.; \& MacBeth, James. 1973. Risk, return and equilibrium: Empirical tests. Journal of Political Economy, 81, 607-636.

Gibbons, Michael; Ross, Stephen; \& Shanken, Jay. 1989. A test of the efficiency of a given portfolio. Econometrica, 57, n.5, 1121-1152.

Hagler, Cristina; \& Brito, Ricardo. 2007. Sobre a eficiência dos índices de ações brasileiros. Revista de Administração da USP (RAUSP), 42 , n. $1,74-85$.

Jegadeesh, Narasimhan; \& Titman, Sheridan. 1993. Returns to buying winners and selling losers: implications for stock market efficiency. Journal of Finance 48, 65-91.

Kimura, Herbert. 2003. Aspectos comportamentais associados às reações do mercado de capitais. Revista de Administração - RAE-eletrônica, 2, n. 1, 1-14.

Murakoshi, Vivian; \& Brito, Ricardo. 2009. Fatores comuns de risco de mercado, tamanho, valor e diferenciais de juros nos retornos esperados das ações brasileiras. Revista de Economia $e$ Administração, 8, n. 2, 253-282. 
Piccoli, Pedro; Souza, Alceu; Silva, Wesley; \& Cruz, June. 2015. Revisitando as estratégias de momento: o mercado brasileiro é realmente uma exceção? Revista de Administração da USP, 50, n. 2, $183-195$.

Shanken, Jay. 1992. On the estimation of beta-pricing models. Review of Financial Studies, 5 (1), 1-33.

Santos, Leandro; \& Montezano, Roberto. 2011. Value and growth stocks in Brazil: risks and returns for one- and two-dimensional portfolios under different economic conditions. Revista de Contabilidade $e$ Finanças da USP, 22, n. 56, 189-202.

Schwert, G. William. 2002. Anomalies and Market Efficiency, in Handbook of the Economics of Finance, G. Constantinides, R.M. Stulz, and Milton Harris (Eds.), North Holland, Amsterdam, 939-974. 
Appendix - Size and $\beta$ in a sample from July 1988 to June 2015

Given the instability of the estimated premiums, noted differences with the previous Brazilian literature, and because inferences about the average size slopes may lack power with only 16 years of data, we perform further test using another database (Economatica) with a longer sample starting in July 1986.

Because the former years comprise extremely high nominal returns generated in a regime of hyperinflation that changed after the mid-1990s, we work with real variables that are more comparable along the whole period. We choose not to include the accounting ratios in the 1988-2015 tests because of the baffling noise in these series caused by the high inflation until 1995.

Table A.1 presents tests when the $\beta$ s of size portfolios are allocated to individual stocks (i.e., "one-pass" size portfolios). It indicates that, along the size quintiles, the positive relation between average returns and $\beta$ s of size portfolios more or less holds from 1988 to 2015 . It also shows how the estimation of $\beta$ as the sum of the slopes of current and prior month E.W.I. returns affect the $\beta$. The regressions of portfolios produce similar results as the regressions of individual stock, taming concerns that the $\beta$ is at a disadvantage in regressions that allocate portfolio $\beta$ s to individual stocks. Besides, the average residuals from the simple regression of returns on $\beta$ s of size portfolios exhibit no relation to size (in the first row named "Regression (4)"). However, when the residuals from the regression of returns on $\beta$ s of size portfolios are grouped using pre-ranking $\beta \mathrm{s}$ of individual stocks, the average residuals tend to decrease with the increase in $\beta \mathrm{s}$ in the regression of returns on $\beta$ alone, contradicting the CAPM prediction of no pattern after the $\beta$-risk extraction (in the second row named "Regression (4)"). 


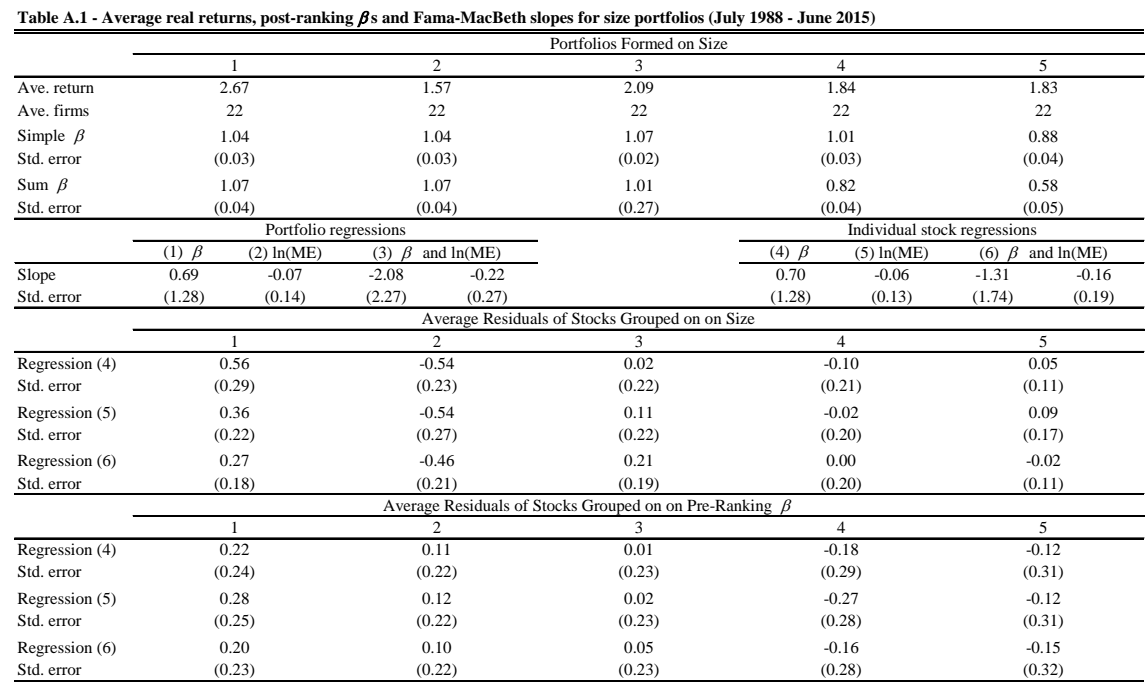

Because the $\beta$ s of size portfolios leave some unexplained variation in returns, Table A.2 subdivide size quintiles into pre-ranking $\beta$ s of individual stocks (i.e., "two-pass" size- $\beta$ portfolios) wondering if the variation in $\beta$ within the size-sorting dimension could explain returns. As described in panel A.2.A, average returns do not seem to monotonically increase with $\beta \mathrm{s}$ within a size quintile. But the sample has not provided much post- $\beta$ variation either in panel A.2.B. This little variation is the reason why, different from $\mathrm{F} \& \mathrm{~F}$, by allowing for variation in $\beta$ s that is unrelated to size does not improve the average residuals tendency to decrease with the increase in $\beta \mathrm{s}$ in the regression of returns on $\beta$ alone in Table A.3.

The correlation between size and $\beta$ is -0.75 for $\beta$ s from size portfolios and -0.60 for portfolios from two-pass size- $\beta$ portfolios. That said, the multicollinearity in the bivariate regressions on $\beta$ and size is obvious in Tables A.1 and A.3, while Table A.2 is more suitable to disentangle these two effects on returns. These estimates in Table A.2 suggest that the size characteristic is more sensible than the $\beta$ to explain returns.

In Table A.4, we see that $\beta$ and size effects are insignificant for the whole period 1988-2015, although they are significant for the July/1999June/2007 period when alone in the regression, coinciding with Table 7 in the main text. But given the high correlation between the market $\beta$ and 
size, neither variable is individually significant when they are used jointly.

Table A.2 - Properties of portfolios formed on size and pre-ranking $\beta \mathrm{s}$ : sample sorted by size then pre-rankng $\beta$ (July 1988 to June 2015)

\begin{tabular}{|c|c|c|c|c|c|c|}
\hline & All & Low- $\beta$ & $\beta-2$ & $\beta-3$ & $\beta-4$ & High- $\beta$ \\
\hline \multicolumn{7}{|c|}{ A.2.A: Average Monthly Returns (in Percent) } \\
\hline All & & 2.40 & 2.40 & 2.14 & 2.20 & 1.98 \\
\hline Small-ME & 2.67 & 2.95 & 3.51 & 2.27 & 2.34 & 2.21 \\
\hline ME-2 & 1.57 & 1.58 & 0.79 & 1.36 & 2.13 & 2.10 \\
\hline ME-3 & 2.09 & 2.40 & 3.57 & 1.82 & 0.90 & 1.68 \\
\hline ME-4 & 1.84 & 1.99 & 1.70 & 1.41 & 2.31 & 1.56 \\
\hline Large-ME & 1.83 & 1.63 & 2.02 & 2.57 & 1.41 & 1.52 \\
\hline \multicolumn{7}{|c|}{ A.2.B: Post-Ranking $\beta$ s } \\
\hline All & & 0.88 & 0.88 & 1.04 & 0.96 & 1.01 \\
\hline Small-ME & 1.07 & 1.11 & 1.21 & 1.02 & 1.12 & 0.86 \\
\hline ME-2 & 1.07 & 1.01 & 0.79 & 1.48 & 1.03 & 1.05 \\
\hline ME-3 & 1.01 & 0.93 & 1.07 & 1.06 & 0.85 & 1.20 \\
\hline ME-4 & 0.82 & 0.79 & 0.71 & 0.87 & 0.87 & 0.88 \\
\hline Large-ME & 0.58 & 0.44 & 0.53 & 0.55 & 0.67 & 0.74 \\
\hline \multicolumn{7}{|c|}{ A.2.C: Average Size $(\ln (\mathrm{ME}))$} \\
\hline All & & 6.77 & 6.81 & 6.75 & 6.80 & 6.67 \\
\hline Small-ME & 4.09 & 4.14 & 4.14 & 4.12 & 4.09 & 3.96 \\
\hline ME-2 & 5.78 & 5.77 & 5.78 & 5.75 & 5.82 & 5.75 \\
\hline ME-3 & 6.79 & 6.80 & 6.83 & 6.79 & 6.76 & 6.75 \\
\hline ME-4 & 7.81 & 7.84 & 7.84 & 7.85 & 7.79 & 7.72 \\
\hline Large-ME & 9.43 & 9.41 & 9.53 & 9.44 & 9.58 & 9.19 \\
\hline
\end{tabular}


Varga, G., Brito, R. D.

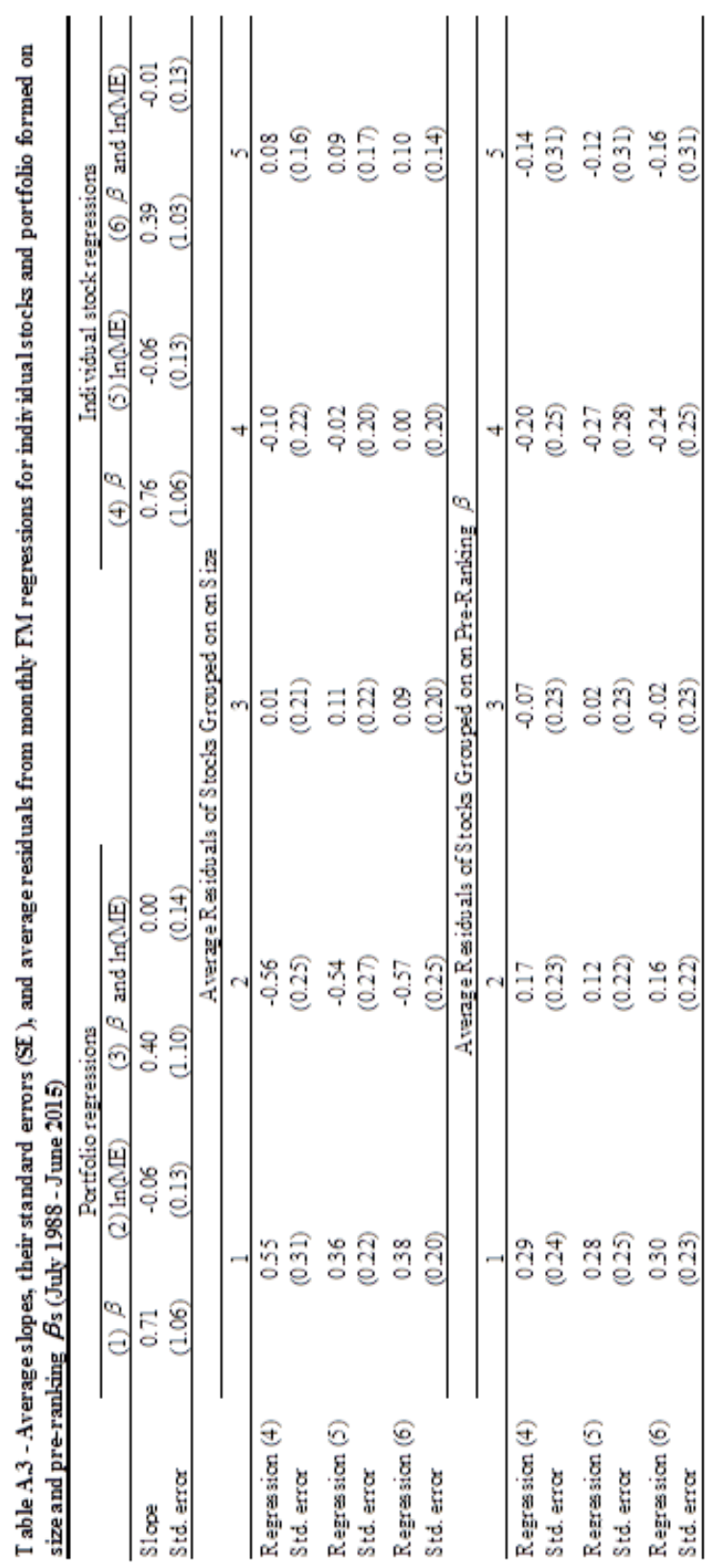




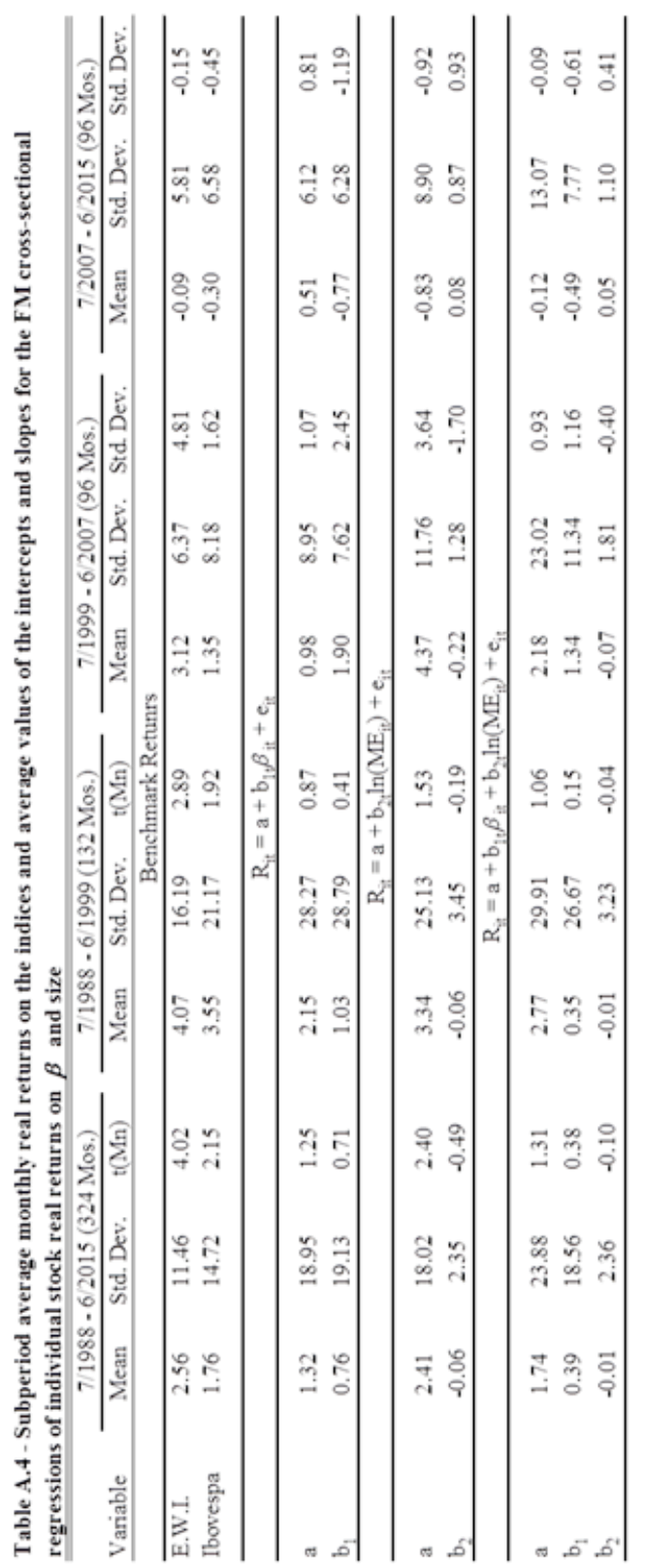

